\title{
Engaging the Authoritarian State: Voices of Protest in Syria
}

\author{
WAed AthamneH and CARoleEn MarJi SAYEJ (New London, CT)
}

\begin{abstract}
This paper captures the discursive interaction between the Syrian regime and the protesters during the revolt that began in March 2011. The purpose of this study is two-fold. First, we trace the use of symbolic rhetoric as a method of control long used by the Syrian regime to shape permissible discourses in society. The Assad family has long relied on the powerful symbols of Baathism, Pan Arabism, and resistance to colonialism to justify its rule with an iron fist. Second, we demonstrate that the protesters are using the same tactics to challenge the regime, as a form of reverse indoctrination, to undermine and counter its dominant narratives. They have engaged the authoritarian state through the use of poetry, music and slogans. The power of their words represents a symbolic collapse of the regime as the protesters negate and reinvent their political identity.
\end{abstract}

Key Words: $\quad$ Arab Spring - Authoritarianism - Collective Resistance - Iltizām (commitment) poetry Semiotics - Syria

Peace be upon you, upon all those who are protecting this dear and precious homeland. Peace be upon the people, the army, the security forces and all those who have been working to insure the prevention of sedition; burying it in the detestable snake holes where it belongs.... Peace be upon the souls of our martyrs whose blood has grown into chrysanthemum in the spring and summer when the seasons of flowering and fruition have been replaced by seasons of conspiracy and killing. But even season of conspiracy gives flowers in Syria. They bloom into pride and impregnability.

Speech delivered by Bashar al-Assad, Damascus University, June 20, 2011

\section{Introduction}

This paper analyzes the discourses between the protesters and the regime in Syria following the uprising that began in March 2011 in which a new genre of literary nationalism has developed from the poetry, writings, graffiti, slogans, and music of the revolt. Since the uprisings began, President Bashar al-Assad (Baššăr al-Asad) sought to frame the issues and

Journal of Arabic and Islamic Studies • 13 (2013): 169-190 (C) Waed Athamneh / Caroleen Marji Sayej, Connecticut College, New London CT 
set the rules of the game of the encounters by issuing a series of statements and speeches about the protests. We will explore how Syrian citizens are using rhetoric and political discourse, methods of control that once served as the backbone of the Syrian regime, to contest the state and undermine its dominant narratives. For decades, Syrians complied with and participated in the huge spectacles of the cult-like regime that used symbolism and other rhetoric devices not only as a form of domination, but also as a means to delineate permissible societal behavior as it "shaped" the Syrian citizen. Syrians are now using the very same tactics - as a form of reverse indoctrination - to undermine the regime's monopoly over the discourse.

The goals of this study are two-fold. First, we hope to build on the assumptions in the literature on authoritarian regime survival by expanding the definition of coercion to include semiotics as domination and how citizens can be coerced by means other than violence, as Assad's regime had done for decades. By addressing the issue of reception (how ordinary people receive, internalize and react to signals by the state), we hope to learn something about authoritarian regime strategies that serves to ensure their political survival. Second, the literary resistance of the protests will give us a sense of the newlyemerging collective identity that is forming with a vision for a post Bashar al-Assad Syria. Through literary analysis, we find a shift in the long-standing poetry of iltizām (commitment) that dominated the region from the 1950s onwards. That literary genre focused on a commitment to Pan-Arabism, combating imperialism, and the question of Palestine. ${ }^{1}$ After the protests of 2011, the people unequivocally rejected the themes of commitment and shifted to demands for individual freedom. Although Assad has tried to keep the former commitment issues alive as a means to protect his regime, the protesters have rejected Pan Arabism, preoccupation with the Palestine question, and Assad's insistence that imperialist powers are conspiring to harm Syrians. We find that Syrian nationalism has been sparked by the political imagination of a population once pulverized under the iron fist of authoritarianism.

\section{Semiotics and Authoritarian Regime Survival}

Studies on authoritarianism attempt to highlight the ripe conditions for transitions, explain authoritarian longevity and refine regime classification. ${ }^{2}$ When trying to account for authoritarian regime-types, the literature suggests that not all authoritarianisms are equal and they use a wide variety of tactics, to different degrees, to ensure their survival. Strategies of coercion (sheer force) and cooptation (buying loyalty) are readily employed not only to keep citizens at bay, but also to shape people's identity and behavior. ${ }^{3}$ Syria, a prototypical "bunker state", uses coercion to gain citizen compliance. It is described as a

1 Arab poets who treated issues of commitment in their poetry include: Tawfĩq Zayyād, Maḥmūd Darwīšs, Samīḥ al-Qāsim, Aḥmad 'Abd al-Mu'ṭi Hijāzīi, 'Abd al-Wahhāb al-Bayātī, Nizār Qabbānī, Șalāḥ 'Abd al-Șabūr and Badr Šākir al-Sayyāb.

2 See LiNZ 2000, LEVITSKY \& WAY 2002: 51-65; SCHEDLER 2002: 36-50, ZAKARIA 1997, GedDES 1994: 104-118, DIAMOND 2008. For works on the Middle East, see BADAWI \& MAKDISI 2007: 813831, PRATT 2007: 91-122, BELLIN 2004.

3 See the discussion in ULFEDLER 2005: 311-334, FJELDE 2010: 195-218. 
country ruled by a minority with little political freedoms. ${ }^{4}$ This single-party regime relies heavily on coercive techniques by way of secret state security apparatuses to rule with an iron fist. Syria has more than 17 such organizations. These single-party or hegemonicparty ${ }^{5}$ regimes are prepared to publicly subjugate their own citizens, like Hafez Al-Assad's brutal crackdown on the Muslim Brotherhood in Hama in 1982. The president acted with impunity, killing thousands of innocent villagers in an attempt to silence the Islamists.

Explanations about authoritarian regime survival focus on state-level and institutional behavior. The literature emphasizes the role of the military, oil politics and the state institutions that buttress these regimes. ${ }^{6}$ Citizens, or "apathetic Arabs" according to some, were not part of the equation. They were depicted as submissive, docile, complacent or loyal to their leaders. ${ }^{7}$ If they were unhappy after all, why were they not revolting? Lisa Wedeen unpacked this problem in her seminal work on Syria, Ambiguities of Domination. ${ }^{8}$ She tackled the modern study of authoritarianism and the legitimacy problem that reduced citizen inaction to fealty. She showed that power is ambiguous and although their actions did not amount to a form of collective action, Syrians were protesting the regime on a daily basis, by way of individual transgressions. She emphasized the power of spectacles in Syria, where symbols of Hafez al-Assad, Bashar's late father, were everywhere, reinforcing his image. She argues, however, that Syrians publicly endorsed the regime as a form of dissimulation but privately pushed the boundaries of compliance and obedience. She offers evidence of a cult of Assad and shows that cult politics has a method and a style of its own. It utilizes a strategy of domination based on compliance rather than legitimacy. Through analysis of movies, humor, political cartoons, and interviews with citizens, she demonstrates that the Syrian regime is absurd and devoid of legitimacy. The regime prolongs itself through the use of empty slogans and public symbolism in order to sustain public compliance. It invests in rhetoric and symbols - safer and cheaper methods - in what she calls the "economy of authoritarian rule." The cult of Assad was powerful not for its ability to induce belief but for its ability it induce compliance, in which people acted "as if" they revered Assad. ${ }^{9}$ In essence, the Syrian regime used this more latent form of coercion - a discursive and symbolic one - to maintain control over society.

The symbolic system exemplifies both political power and the regime's vision of nationalism. The spectacles are powerful and publicly visible. Images of the ruling family are everywhere. Hafez al-Assad was always depicted as a father figure and the public spaces crawled with pious images of Assad's mother with a halo. Even cars, taxicabs and homes adorned pictures of the Assad clan. The regime regularly used repertoires of

4 A detailed discussion is found in HENRY \& SPRINGBORG 2001: 99-167.

5 The literature on regime classification offers a variety of categories for states. Countries such as Syria have been classified differently at various points in history, ranging from totalitarian, military, singleparty, politically closed, and hybrid. See full discussion in DIAMOND 2002: 21-35.

6 Examples include FISH 2002 and ROSS 2001. For a lengthy theoretical discussion, see BRYNEN 1995 and 1998.

7 The assumptions about Middle Eastern societies are summarized in KELIDAR 1993. Some of these assumptions are deconstructed in ROGAN 2009.

8 WEDEEN 1999.

9 Ibid.: 6 . 
symbols $^{10}$ to guarantee citizen familiarity and participation in the game of spectacles. School children, for example, were regularly called to march in demonstrations pledging loyalty to the president. In a country where "even walls have ears," political jokes were coded and people regularly invoked the name of the president and his family to avoid punishments. By relying so heavily on symbolic rhetoric, the regime killed political activity outside of the parameters set by the state, thereby delineating the norms and limits of political behavior.

Symbols used by the cult regularly invoke Syria as the main representative of Pan Arabism. Assad took great pains to keep the Palestine issue alive, remind people of Israel's occupation of Arab lands and to highlight the deep impact of colonialism on states in the region. His rhetoric seems to reveal the growing disconnect between regional (Pan Arab) politics and the Baath state's position in it. During the Cold War this party platform mattered. It was about secular Arab republican values. The Baath party was used to hold the country together and move away from sectarian definitions. In 1963 Hafez al-Assad's coup purged the party. His style of leadership, continued by his son, was to accrue power by forging a network of powerful elites, which connected businessmen to state officials. The patronage network is about money, power and loyalty, and includes a mix of elites from different religious backgrounds. During Arab-Israeli wars, the Baath and Pan Arab logos were useful. But the realities of the 1973 war eventually settled in. Syria was not getting back the Golan Heights. Egypt made peace with Israel in 1979. The Palestinian question continued to linger. Many regimes in the region began to cooperate with the U.S. after the fall of the Soviet Union and more so after 9/11 and the Iraq War. When George W. Bush famously stated, "either you are with us or with the terrorists," it was very difficult for states in the region not to take Bush's statement (or threat) seriously.

Prior to the U.S. invasion of Iraq in 2003, some texts referred to Syria and Iraq as the last-standing representatives of Pan Arabism. ${ }^{11}$ The Syrian regime did not forge diplomatic relations with the United States or tone down regional Arabism rhetoric. After the fall of Saddam, Syria was the "lone" Arab confronter to regional and international threats. Syria outwardly opposed the 2003 invasion when other Arab countries fell silent. Syrian rhetoric is frequently directed at imperialism or the threat of it. Despite this rhetoric's inability to connect with citizens' needs, such as rising unemployment and a severe drought that incapacitated the agricultural countryside, the regime regularly reminds Syrians of the pressing regional issues and the important role Syria plays as the "last-standing Pan Arab nation." Before protests began in 2011, Syrians continued to behave "as if" they believed the narratives presented by Assad. While other regimes in the region use rhetoric and symbolism, no regime utilizes this strategy to the same degree as the Syrian one. Bashar alAssad continued this strategy laid down by his father.

10 We borrow the term "repertoire" to capture what Charles TILLY meant when he described English social movements of the eighteenth and nineteenth centuries. He talked about "contentious gatherings" in which activists build on previous actions to refine their collective responses. These repertoires work to create a sustained and standardized response to the state. See TILLY 2008: 15.

11 See FAWN \& HinNEBUSCH 2006. 


\section{The Framing of a Political Crisis}

After protests began in 2011, Bashar al-Assad simultaneously used the classic strategies of coercion and cooptation in an attempt to overcome the political crisis. His use of symbolism and other rhetoric devices - the subtle and economical versions of coercionwere meticulously laid out in all of his public pronouncements since the start of the revolt. That strategy, and the themes which he repeated with precision, were meant to contain the voices of protest and redirect them in accordance with his agenda. Despite his efforts, we find that the protesters, well-versed in the regime strategy, worked both to undermine and to move beyond the regime's narrative.

In a now famous but rare interview granted to the Wall Street Journal in January 2011, Bashar al-Assad stated, "If you want to talk about Tunisia and Egypt, we are outside of this; at the end we are not Tunisians and we are not Egyptians." A few years later, the embattled leader found himself in the middle of a bloody uprising that quickly devolved into a brutal civil war. In reaction to the protests, analysts were quick to point to the fact that all the leaders in question initially had the same reaction, and eventually capitulated when their tactics and narratives fell short. Leaders of Egypt, Tunisia, Yemen, Libya and Syria were quick to blame terrorists and infiltrators as the instigators of violence. They underplayed the severity of the problem, censored the media, promised pay raises for government employees, gave families stimulus packages, initiated reforms and in some cases, promised not to seek another term in office. Ultimately, the Tunisian, Egyptian and Yemeni leaders were not willing or able to turn on their own citizens. In the cases of Egypt and Yemen, the close alliance, and by extension reliance on the United States prevented these leaders from alternative courses of action. Assad regularly flaunts his independence from the West.

Many thought Syria was one of the least-likely places for demonstrations. It is a totalitarian police state where the use of force is always an option. Given its minority rule status, the Assad clan has a strong incentive to survive. Like other leaders, Bashar tried to make a series of concessions, including the initiation of reforms, the lifting of emergency law, and the release of political prisoners. He tried to keep an open line of communication with his people as he called for an inquiry into civilian deaths, granted general amnesty to political groups, and invited the opposition to talks. By early 2012, there was a new constitution and party law in place, alongside the implementation of new presidential provisions. However, Assad initiated these reforms while he systematically worked to suppress the revolt. Evidence of widespread detentions, torture, targeting of civilians, especially massacres of women and children, and an army assault on towns were documented on the Internet. It was clear that Assad's government would not fall easily.

Since the uprisings began, Assad delivered several speeches and gave a few interviews that addressed the uprising. In them, he comes across as humble, informal, apologetic, and patient. All of Assad's speeches are riddled with stories of Syrian unity, vaulting nationalism, imperialism, commitment to Palestine, regional threats to Syria, and the need for gradual reform. He always presents the situation as one in which Syria has a special place in the region and the long list of distractions have been responsible for citizen dissatisfaction. In several statements, he acknowledged that he was absent from the public eye for long periods of time and that his speeches were late, but attributed this to his desire 
to prepare rational and balanced responses to his people (People's Assembly Speech, March 2011). He delivers constant reassurances that he is calm, consultative, pensive and careful not to entertain propaganda. He stands firmly against imperialism and terrorism with statements about punishment, followed by assertions that Syrians can be forgiven. $\mathrm{He}$ offers Syrians many opportunities to abandon the uprising and revert to the status quo.

All his speeches have a totalizing element to them. They are all virtually the same, regardless of where Assad finds himself in the conflict. He repeats the same themes and seems to want to reduce citizen expectations throughout, expressing that Syria has been dealing with conspiracies throughout its history. In all his pronouncements, he adamantly denies that he is facing a popular uprising and blames all the violence on "terrorists," "saboteurs," and "conspirators" sometimes focusing on terrorists groups and other times on the imperial powers that have dreams of partition, as "the grandkids of Sykes-Picot" (January 2012 speech). There are intermittent specific references like the one to the 1916 British and French partition plan above, but for the majority of his speeches, Bashar simply refers to all crises as "the events," as if not stating them will make them less real. Moreover, he is in constant denial of what the world sees, making several references to fabrications and what he calls misrepresentation of himself so that he would "appear as if he lives in a cocoon" (Damascus University Speech, January 2012).

Assad makes links between the protests and terrorism, framing the rebellion as a foreign conspiracy. He argues that the Syrian uprising was driven by imperialist powers, as part of a global conspiracy fomented by countries such as the United States and Israel, as they work with local Arab countries, including Lebanon, Saudi Arabia and Qatar. While other countries caved from external pressures, Assad warned of the need to stay unified against imperialism. While he acknowledged a legitimate regional will of the people, like that of the Palestinians, he denied its presence in Syria. According to him, there is no such a thing as an armed resistance movement - these are terrorist cells aided and funded by the West. He claims that he is having a hard time defeating the terrorists because they are being supported by international (imperialist) countries. In June 2012, Assad declared that "the masks were lifted, the international role has been revealed, the regional role is exposed and colonialism will always be colonialism," in reference to the news that Western powers were giving aid to the rebels. ${ }^{12} \mathrm{He}$ attempts to conjure up Arabism images in hopes of angering Syrians at the prospect of intervention and partition, with analogies to Iraq and Palestine.

He spends a lot of time talking about the "enemies of the homeland." The "conspirators," clever, organized and methodical, are "mixing up elements" in order to confuse innocent people. He argues that people were told to protest for reform, but in fact these were acts of sedition that included vandalism, the targeting of schools, satellite and Internet

12 By early 2013, the United States, Europe, Turkey and the Gulf countries had supplied non-lethal assistance to the rebels, including communication gear and generators. They had fallen short of providing anti-aircraft weaponry that the rebels had requested. In June, President Obama changed course and declared a commitment to arm the rebels in Syria based on the urgency of the situation on the ground. In addition to the reported 100,000 civilians killed, Bashar Al-Assad seemed to turn the tide against the rebels with the help of Hezbollah fighters from Lebanon and a steady supply of weapons from Russia. 
fabrications, and sectarian methods to instill hatred. He frames the problem as one in which a small group of terrorists, preying on innocent civilians, manipulated the language of reform or tricked civilians into violent acts. He gives examples of lies told to neighbors to make them paranoid and defensive (People's Assembly Speech, March 2011). He argues that while this type of plot is not new in Syria, it is a complicated by the new technology and tactics that are harder to foil. Based on Assad's pronouncements, the only options are that the protesters are terrorists, the West is responsible, and Syrians need to resist "as usual" in the face of colonial aspirations. There is no room for more discourse.

The majority of Assad's speeches are focused on reform. He argued that they were underway for years, a point he repeatedly reminded his listeners in every speech since March 2011. He talked about giving Kurds citizenship, the need for modern media laws and the eradication of corruption to match the "maturity and intelligence level of the people" (Speech to the New Government, April 2011). He then elaborated on the problems in Syria that need to be addressed, including unemployment, youth despair, and the drought that left the agricultural sector in shambles. Assad is most adamant in the claim that none of the reforms initiated were due to either internal or external pressure, because that would mean they were not genuine. In fact, he says that reforms already existed as draft laws, as early as 2005. The emergency laws, for example, existed in 2009, according to Assad. He offers explanations, not excuses, for delays in reform. These include the attacks of 9/11, which resulted in the U.S. targeting of Muslims, the occupation of Iraq and Afghanistan, and more generally problems with Lebanon and Israel. Assad argues that he is made to "pay the price" for standing up to the United States (People's Assembly Speech, March 2011). These official explanations are classic, albeit hackneyed repertoires in Syrian discourse.

In the early months of protest, Assad wanted to take back the streets as he showed his forgiving, patrimonial side. He excused those who mistook reform for "destruction." $\mathrm{He}$ acknowledged that well-meaning innocent Syrians were duped by "saboteurs" who were small in number, but effective (Damascus University Speech, June 2011). He argued that the state does not take revenge on law-breakers; "a state is like a father and mother," giving love. He repeatedly urged refugees to come home, since there would be no punishments, only amnesty and tolerance. In every speech, he offers Syrians a chance to back down as he wishes "his heart was bigger to show more love to his citizens."

By January 2012, however, Assad took an increasingly offensive posture. He made several direct references to the United States, the "dealers of freedom and democracy," that wanted a snowball effect in the region after the 2003 Iraq War. He mocks the neoconservative argument that there would be a ripple effect of democratization after the fall of Saddam Hussein. ${ }^{13}$ He even mentions his December 2011 interview with Barbara Walters and alleges that the interview was filled with "professional fabrications" as he casually offered to make public the original tapes. He said that over 60 satellite television

13 FEITH 2009 elaborates on the official U.S. military objective during the Bush presidency of not only removing Saddam Hussein from power, but also overturning the regimes in Iran and Syria. Feith, under-secretary of defense under the administration of George W. Bush, confirmed the U.S. desire to remake the map of the Middle East. 
stations were part of the conspiracy to destroy Syrian unity, prompting him to ban media outlets from entry into Syria.

Assad's language on Syrian nationalism, Pan Arabism and the need for unity was strongest in the January 2012 speech than anywhere else. Perhaps this was part of his attempt to appeal to the nationalists among the opposition. He argues that "Arabism is not a slogan, it is a practice." He talks about Syria's overwhelming international legitimacy. He takes issue with Israel, which he describes as an occupier, devoid of international legitimacy in its actions. He attacks the Arab League with his pronouncement that "suspension from the Arab League is a suspension of Arab identity." He refers to the organization as a "mock-Arab" body and suggested that the league replace Syria with Israel. He had hoped to deflect attention away from domestic problems and to draw attention to regional problems. He was reaching out to Palestine sympathizers. He completes his attack of the outside by reminding everyone of Palestine's fate. He manages to show some flexibility, however, when he concludes "we don't close doors, we are happy to hear a solution that respects Syrian sovereignty."

As the months passed, Assad increasingly painted the conflict as a black and white issue, much like the framing of the "War on Terror" by the administration of George W. Bush. He warned that "standing on the fence" was not an option. He first acknowledged that treatment of these terrorists would not be subject to state standards, much like George Bush proclaimed that "nonstate actors" were not subject to Geneva Conventions or the rules of war. For Bush and Assad, they don't apply to terrorists. In the most stark follow up, he says, "either you are with us or against us," like the famous "with us or against us" in Bush rhetoric. He warned that the end would only come when Syria abandons "Pan Arabism, the 1973 heritage and Palestine-which is never" (Damascus University Speech, January 2012).

Many analysts have described Assad as "living in a cocoon," a phrase he acknowledged in his speeches. The dilemma rests in the conflict between his beliefs and his survival tactics. He framed the issues using the same narrative throughout the conflict, regardless of what was transpiring on the ground. Perhaps he is both delusional and living in a cocoon because he bought into his own rhetoric of grandeur, a product of the cult of personality. Either way, he was engrossed in rhetoric, which prevented him from stepping down or negotiating a solution.

While all the regimes of the Arab Spring started with the same discourse and initiated the same reforms, the Syrian regime sees no end in sight. Perhaps the pressures of being friendly with the West and the United States pushed Mubarak, Saleh and Ben Ali out quickly. But the cult of Assad also plays a major role. The regime has elevated itself to an invincible, godly status granting itself impunity to act at all costs. These actions would not have worked in Egypt, Tunisia or Yemen, because they are not in line with the regimes' discourses. The discourses in Syria, framed and reframed over decades of indoctrination, have shown that the use of rhetoric as an authoritarian survival tactic clearly shapes and contours the discourses of the people.

\section{The Streets Speak}

Lisa Wedeen's work highlighted the role of individual transgressions in Syria under duress, as the regime set the parameters of permissible political discourse. Now, there are no rules 
and no compliance. Protesters are demonstrating that they are not simply the blind followers of Assad's cult, as Wedeen argued years earlier. The turn of events shows Syrians challenging the regime by using the very same tactics and methods once employed by the state. They have taken the challenge to a whole new level, through the use of poetry, music, and slogans. Syrians are intentional in their repertoires, discursive approach, and organized resistance. Through a brief survey of the literature, we see a clear rejection of the "commitment" discourses laid out by Assad. Not only are protesters working to undo the Assad narrative, but also they are introducing new themes into the discursive field. ${ }^{14}$

The resistance in Syria has morphed over time, from peaceful demonstrations to armed resistance with a wide range of groups under each banner. In addition, there is a regional component to the resistance, with connections to jihadist networks becoming more pronounced. Though the wide range of resistance trends may appear as a confounding factor, we are concerned with the repertoires - the prevalence of public pronouncements and utterances used by protesters. It is the repetitive, public aspect that allows the expressions to be imprinted in the memories and imaginations of Syrians. As people internalize the symbols of resistance, the repertoire becomes one piece in the puzzle of national identity-building. The multiplicity of voices will give us a sense of the trajectories, at times competing, that make up the Syrian imagination today. While our study is not exhaustive of all voices of protest, it offers some early examples of the public narratives that have surfaced in Syria for the first time in resistance to Assad's rule. It is a first step in understanding the interaction between state and society when the traditional tools of authoritarianism break down. ${ }^{15}$

\section{Poetic Confrontation}

In the context of the Arab uprisings, poetry and poetic slogans play a key role in continuing the old tradition of literary resistence. Many modern Arab critics and poets believed in the poet's role in politics and society and encouraged the Arab intellectual to write for the people, especially since Arabic poetry gave shape to their struggles and aspirations. Poetry also served as a medium for the advancement of social and political thought, such as movements for Arab unity. One of the key notions of iltizäm in modern Arabic literature is the writer's duty to shape the feelings and aspirations of the nation, and most importantly, to awaken the sense of nationalism in the Arab public and to raise caution in the face of

14 Other works have been conducted on the literary importance of the revolts in Syria. Examples include FILALI-ANSARY 2012. This work is an attempt to contextualize the creative expressions of dissent in Syria and to make sense of the new political language of the Arab Spring for the new generations of the Arab world. In another example, "Culture in Defiance" is an art exhibition in Amsterdam dedicated to the creative struggle for freedom in Syria, opened by political cartoonist Ali Ferzat. It is accompanied by a publication with the same name that demonstrates how the resistance movement is reclaiming the public space from the state.

15 There is no way to gauge the percentage of the population that participates in protests or to conduct a time-series analysis that connects regime and resistance discourses. Many of the songs, poems and slogans are anonymous and undated. Yet they retain their value for their ability to flood the public sphere and to entice Syrians to repeat them. This function allows the literary resistance to shape the new narratives that are surfacing among segments of the Syrian population. 
social and political ills. One of the duties of the Arab poets of al-adab al-multazim requires the authors to engage the reader in topics and issues of concern to the Arab public. This did not come without controversy. Arab intellectuals in the 1950s were split in their views on the purpose of art between those who believed that art should be for art's sake and those who believed in iltizām. Sa'dallah Wannūs (1941-1997), a Syrian playwright who wrote about social criticism and Arab political decline, argued that the Arab writers who escape in their writings from the military and political defeats of their societies and "the many revolutions crushed by colonial, neocolonial, and Zionist pressures," are tempted to escape from their realities by writing about their "idealized golden past" or "predetermined glorious future"-which in itself is an ultimate defeat. ${ }^{16}$ Also, Egyptian scholar Salāma Mūsā (1887-1958) was interested in the function of literature in society and demanded that the Egyptian writer should "abandon his ivory tower and share the life and fate of his people." ${ }^{17}$ However, opponents of the committed literature of the 1950s considered it incompatible with the freedom of the writer and accused it of being "full of propaganda and providing stereotypical description of the grievances of the poor." ${ }^{18}$ Thus, modern Arab critics and poets were devided between those who believed in art for art's sake, and those who believed in the social and political 'mission' of literature. After the humiliating loss of the 1967 War against Israel, many of the proponents of commitment lost their belief in the political role of the writer and the effectiveness of the literary word. ${ }^{19}$ The loss of Arab territories to Israel in six days revealed the ineffectiveness of the regimes in power and the Arab nationalism they touted.

After 1967, the effectiveness of the literary word was questioned alongside the reader's ability and willingness to change his reality. Therefore, many Arab poets grew tired of writing for the silent people who seemed to accept their fate. The modern Arab poet, while acknowledging the role of poetry in society, lamented the public's silence and paralysis. If people choose not to read poetry or believe in their poets, even the most provoking poetry fails in making the slightest of change. Thus, during key political events, like the Arab uprisings, poets are inspired to respond through poetry. During such times, the Arab poet not only sees a different Arab individual, but also a potentially different Arab reader. For the first time in many decades, many Arab readers find in Arabic poetry a correlation to reality. Such a change has an equal impact on the reader and the writer. A poem written about the uprising in Libya, for example, finds its echo in the streets of Egypt and Syria. Arab poets who write for democracy, freedom of speech and the liberation of people in any Arab country write in defense of Arabs and humanity across the globe. Indeed, poetry can be "as good as dynamite" if written by a revolutionary poet, in a revolutionary language at a revolutionary time. ${ }^{20}$

Poetry has been a prominent political tool during the Arab Spring uprisings. It is among the most popular mediums for Syrian revolutionary resistance. In engaging the regime, prevalent themes in Syrian poetry include Assad's shortcomings in precipitating Israeli

16 KASSAB: 2010: 63.

17 ISSTAIF 2002: 172.

18 KLEMM 2000: 53.

19 Ibid.: 58.

20 JABRA 1980: 192.

$J A I S \cdot 13$ (2013): 169-190 
withdrawal from the Golan Heights, the alleged conspiracy against Syria and Pan Arabism, and the violent history of the Syrian regime. Two popular poems include, "Muqāwim bi'lTharthara" (Resistant by Chatter) by Aḥmad Mațar and "Aḥmaq, Masțūl, Kaḍdāāb" (Foolish, Dumb, Liar) by an anonymous writer. Ahmad Mațar (b. 1954), an exiled modern Iraqi poet, has been living in London after fleeing Kuwait in 1986 for being critical of Arab regimes. He is known for his satire and revolutionary political poetry that addresses the status quo in the Arab world. His works lament the status of the Arab world with an emphasis on corrupt Arab leaders, the lack of civil liberties, and the indiscriminate use of force by rulers who cling to power. Mațar, an Arab nationalist and social realist, wrote poetry to defend the Arab individual's basic rights to freedom and democracy. His recent poem, "Muqāwim bi'l-Tharthara,"21 was written in 2011 to support the Syrian uprising, criticize Assad's regime, and empower the protesting Syrian voices against Assad.

Mațar enters into a dialogue with the Syrian regime by negating some of the major themes in Assad's addresses to the people.

\section{Resistant by chatter}

Opposing by chatter

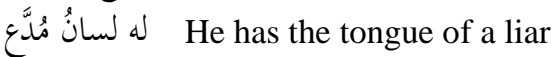

يصولُ في شواًرع الشَّامِ كسيفِ عنترة

He roams the streets of Syria like the sword of "Antara

يكادُ يلتَفْ على الجولانِ والقنيطرة

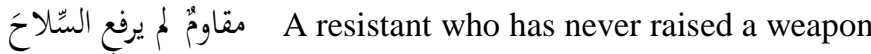

Has never sent a tank or an airplane to his Golan

Has never opened fire at the enemy

But when the people spoke,

He awakened from his dream

And yelled to his men:

مؤمرة "Conspiracy,

مؤامرة Conspiracy."

و وأعلنَ الحربَ على الشَّعبِ

A And his response to their talk was a

بحَزْة Massacre.

مقاومٌ يفهُمْ في الطبّ كما يفهمُ في A resistant who understands medicine as well as he

understands politics

He retired from the eye clinic

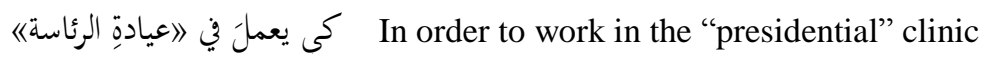

$21<$ http://www.ibtesama.com/vb/showthread-t_273529.html> (in Arabic). 


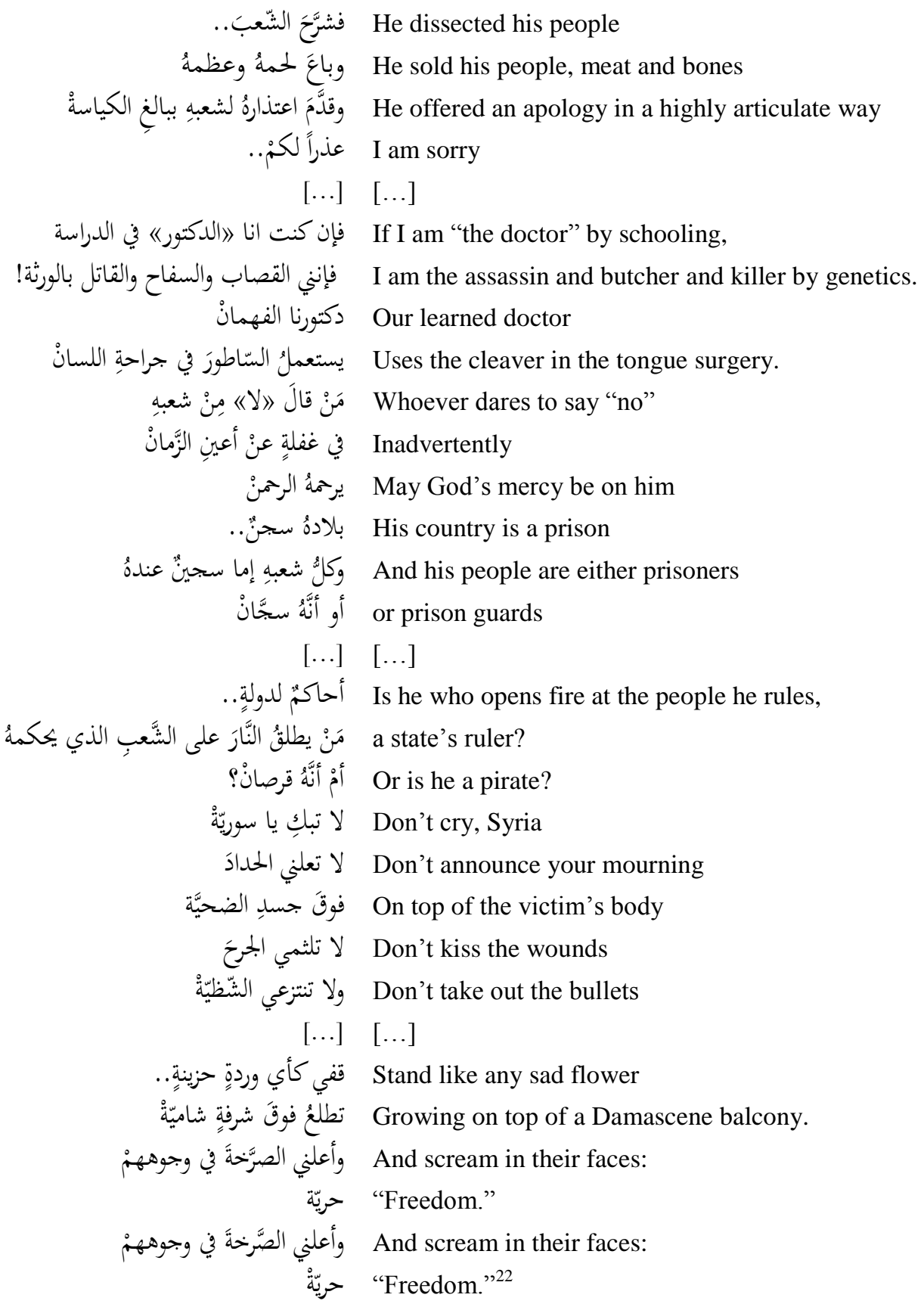

$22<$ http://www.ibtesama.com/vb/showthread-t_273529.html> (in Arabic). 
In the first stanza of the poem, Mațar addresses Assad directly as a leader who is good at "chatter," but unable to fight the enemy (Israel). Mațar uses satire to ridicule Assad and his supporters. He asks rhetorical questions to emphasize Assad's illegitimacy to rule and to awaken a sense of awareness in the people. Wondering how Assad could call himself a resistant when he has never opened fire at the enemy, Mațar associates resistance and legitimacy with fighting the enemy (Israel) and restoring the occupied territories. He portrays Assad as a coward when it comes to fighting the enemy, and as a brutal butcher when it comes to silencing the opposition. In this image, Assad hovers over Syria as a hero who is about to recapture the occupied territories. Mațar ridicules Assad's claims to guard pan-Arabism, like his father before him, by questioning his stance on the Israeli occupation of the Golan Heights of Syria. Mațar shows that in the presence of real threats from the outside, Assad responds with chatter, or rhetoric. His inability to restore the Golan Heights is juxtaposed with his actions against Syrian protesters. The minute they "spoke," he reacted violently to their "talk," and embarked on a killing rampage. Ironically, Assad finishes his criminal acts by articulately apologizing to his people. By this, Matar means to tell Assad that apologizing after killing people will not do him any good, because his tactic is no longer effective. Assad's apologies to his people are plentiful, as illustrated in his presidential speeches.

Mațar uses stark images to surprise his reader. He portrays Assad as a butcher who dissects his people and sells their meat and bones. Like his father, he is "the assassin and butcher/and killer by genetics," a reference to the Hama massacre and an indication that Bashar's actions are in line with his predecessor. Matar also mocks Assad's medical background. A doctor who took an oath to "do no harm" is using the techniques employed during "autopsies" and "surgeries" in his violence against the people. He highlights Assad's disproportionate response when compared to the real dangers posed by Israel. This reveals Assad's colossal failure in his Pan Arabism goals. He is a "coward" against Israel and a "bully" with his own people. In doing so, Mațar defends the Syrian opposition's right to resist Assad and encourages them to call for freedom. The call for freedom from an Iraqi poet intensifies and shapes the feeling of pan-Arabism, a feeling that Assad and other Arab leaders failed to make a reality. Arab leaders have been using the Arab nationalism project to garner support while simultaneously implementing emergency laws and ruling without decree as they tackle "bigger" issues. Mațar adds his voice to that of the Syrian opposition and reminds it of the regime's lack of tolerance toward civil disobedience. Matar maintains that Assad, like his father, only used the "conspiracy" tactic to silence the people through "emergency laws." Mațar also calls Assad a pirate, lacking the legality, official mandate, and authorization to rule. In this Mațar encourages a lawful democratic movement in Syria. The protesters are encouraged to stand firm and to resist at all costs as they yell, "freedom." The bloody images portend the fate of these people.

Matar is addressing not only the Syrian and Arab opposition, but also the Syrian regime. He is sending a message to Assad by shaping the feelings of the Syrian opposition and its supporters toward the regime. He represents the voice of Arabs across the region, consistent with the revolts in other Arab countries. Matar's poetry adds a Pan Arab dimension to the voice of resistance against Assad and other Arab leaders. In his poetry, Arab intellectuals, poets, and the public revolt against Assad and ridicule his regime irrespective of their nationality. In a more successful use of Pan Arabism, Mațar exposes 
Assad's bankrupt rhetoric and works to negate and deconstruct it. This stage is very critical in both Arab politics and literature.

Since Assad's legitimacy has been openly questioned since the beginning of the uprising in 2011, poets like Matar seize the opportunity to attack the regime and incite the opposition to resist it. Matar wrote political poems all his life, but it is during key events like the uprising that such poems become widely read and better received. The uprising did not make Mațar a committed poet, rather, it gave his committed poetry context and inspired him to continue writing poetry. Many Arab poets wrote poetry in an attempt to defend their people and societies against their dictatorial regimes only to discover that the Arab public is unable or unwilling to fight back. Despite that, some poets continued to write this kind of poetry, like Mațar. In continuing to write political poems during the uprising, Mațar is making a bold statement in literature. He is not only declaring to his readers that he has never abandoned them, but also making a more public pronouncement that the Arab nation he spoke of in his poetry has finally resurrected and is marching in the streets against injustice. This literary resistance has reached a juncture in which art is imitating life. Iltizām is no longer about a yearning for action, but it is becoming a reality as protests are underway in Syria. In Jāhilì times, poets wrote poetry to defend their tribe and incite their kinsmen to fight against their enemies. In this poem, Matar becomes the poet of the opposition/protestors, who writes poetry to defend the opposition's uprising against their ruler. Mațar's poem functions as a literary articulation of the politics of the war. Matar stands with the protestors and encourages them to resist the regime and its long history of violent rule. Mațar writes in reaction to Assad's multiple discourses not only to declare his opposition, but also to reject Assad's rhetoric and reform attempts altogether. $\mathrm{He}$ documents in poetry what politics might fail to stop. Mațar uses this poem to lament what Syria has been reduced to: a prison in which the Syrians are either prisoners or prisonguards. Assad has literally turned Syria into a state of fear. Mațar ends the poem with a message of defiance. He asks Syria to endure its wounds and resist until the end, because freedom is on the doors.

In another poem, "Aḥmaq, Masțūl, Kad $\underline{d} \underline{a} b$ " (Foolish, Dumb, Liar), an anonymous writer criticizes Assad, the Baath regime, and the reform initiatives ${ }^{23}$.

$$
\begin{aligned}
& \text { Foolish, dumb, liar } \\
& \text { He creates history by a speech } \\
& \text { I told the foolish.: "I have a crisis. }
\end{aligned}
$$

23 Much of the literary resistance in Syria is anonymous. During the early months of protests, the regime's reaction to deter future protesters included grotesque strategies. In one example, Syrian security forces ripped out the vocal chords or a young cement layer from Hama, Ibrahim Qashoush, for singing the revolt’s anthem, "Yallā irhal yā Baššār" (Come on Bashar, leave!). Other incidents include the August 2011 beating of Ali Ferzat, the most famous political cartoonist in Syria. He has drawn over 15,000 caricatures over his lifetime, sometimes in official Syrian newspapers. The beating, which was meant to mangle his hands, was a "message" that his recent caricatures in support of the revolt would not go over well with the regime. The Internet is also flooded with gruesome images of torture, especially of children, at the hands of the regime. 


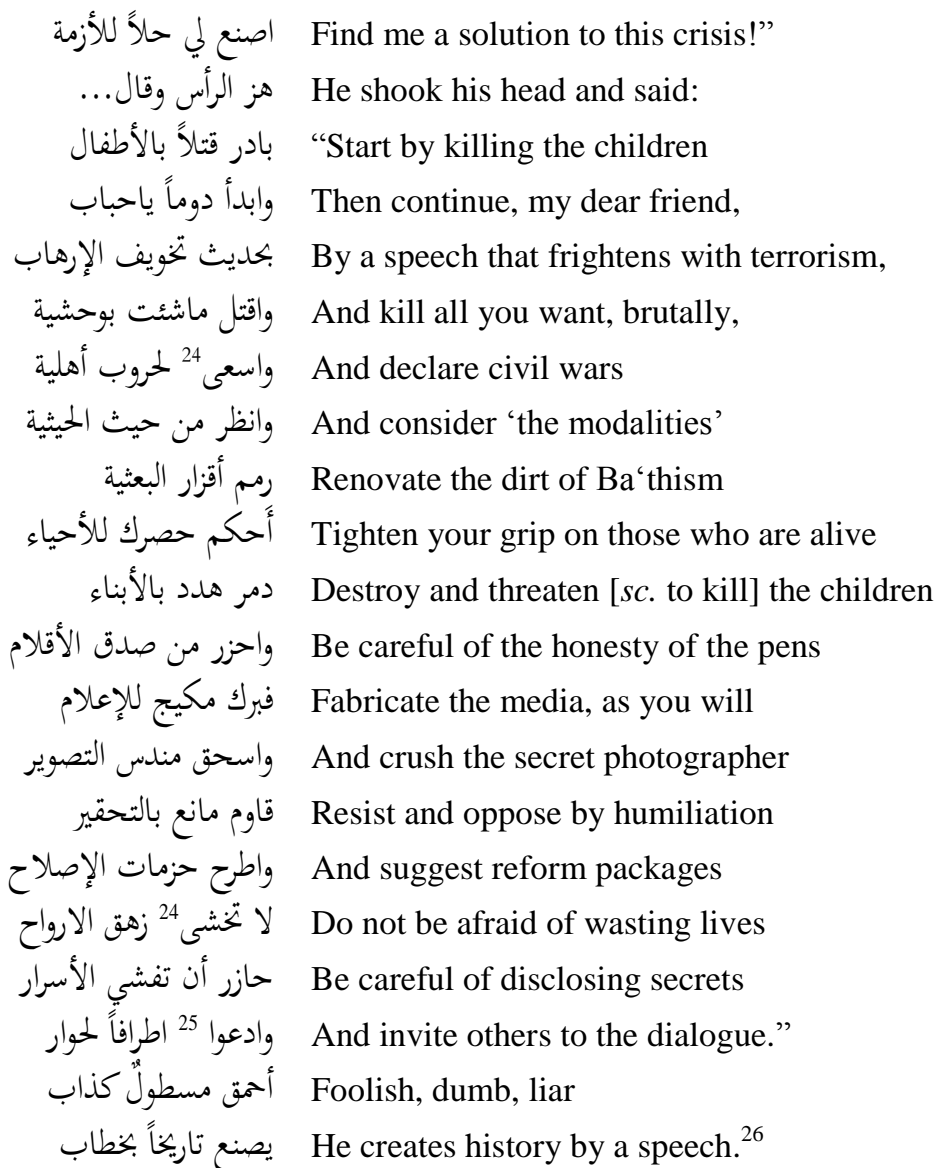

The speaker voices the people's frustration with the regime and demonstrates their deep understanding of the hidden agenda of the Baath party. Assad, who spent his years making "discourse/speeches," is a foolish liar who is unable to deal with the crisis in Syria, but instead resorts to the decades-old strategy of delivering speeches and ratcheting up the rhetoric. Lacking judgment, Assad reacts to the crisis by killing children and initiating a civil war, instead of initiating dialogue or undertaking genuine reforms. Assad is portrayed as an extended metaphor to the violent Baath party that claimed to unify Arab countries under the umbrella of Arab nationalism. It is the "dirty" Baath party that ordered the massacres and humiliation of Syrians in the name of Pan Arabism. Assad, under the Baath, lied repeatedly to the public and the media by inviting the opposition to discuss their demands in a civil dialogue. Assad chose to declare wars, kill children and further the

24 The verbs appear like this in the original text. The correct forms should be $w a$-'s' $a$ ع́m and $l \bar{a}$ tahša لا تخشَ, with short - $a$, for imperative and apocopate/majzūm, respectively.

25 The correct form should be $w a$ - ' $^{\prime} u$ ' $\dot{y} \mathrm{~s}$, with short $-u$ for imperative singular (not plural).

26 <http://www.homsnet.com/forum/showthread.php?p=557171> (in Arabic). 
Baath agenda at the expense of the population. In this context, the Bath party is completely discredited, as the people are neither interested in dialogue nor willing to endure humiliation under Assad's regime. Therefore, the discourse at this stage with the regime reveals not only a stark directness, but also a developed sense of maturity. The people now address the regime in the same way the regime addresses them. What is even more significant at this stage is the use of poetry to spread the word. Poems like this use everyday language that makes it easy to memorize. The regime can no longer use Arab nationalism or pan Arab slogans and dreams to impose its own agenda on people and distract them from their quest for freedom. People are outwardly rejecting the Baath and Pan Arabism. This is a big milestone since Arabism has been the ideological linchpin of Syrian identity. In the end, Assad is a "liar" who fabricates the media to protect his regime and torture those who oppose him. He is "foolish" because he is unable to solve the crisis in Syria, but instead incites a civil war among the population. He is "dumb" because he does not realize that neither death nor humiliation can stop the people from resisting his strong grip.

\section{The Beats of Resistance}

In a song written in 2011, the Syrian youth respond to Butayna Ša'bān 's address to the Syrian people that promises economic reforms. ${ }^{27}$ Sha'ban has been political and media adviser to President Assad since 2008 and "the regime's face to the outside world." The title of this song is "Bidna hurriyya wa-bass" (Freedom is All We Want). Written in the Syrian dialect, this song reflects the new level of the Syrian people's discourse with the regime. From the first line of the song, the speaker engages in a direct dialogue with the regime by addressing Butayna Ša bān's speech:

$$
\begin{aligned}
& \text { O ما بثينة ويا شعبان الشعب السورى مش O Butayna Šachān, the Syrian people is not }
\end{aligned}
$$

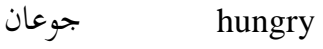

$$
\begin{aligned}
& \text { It only demands freedom } \\
& \text { No one can humiliate the Syrian people, neither in } \\
& \text { Dar'a nor in al-Tall } \\
& \text { Only look at al-Lādhiqiyyah, it is calling for a } \\
& \text { peaceful revolution } \\
& \text { But the security forces and intelligence cannot } \\
& \text { understand these words } \\
& \text { وها الدولة البوليسية بتغتال كلمة قضية And this police state assassinates our cause } \\
& \text { Hafez was the father of reform }
\end{aligned}
$$

27 <http://www.youm7.com/News.asp?NewsID=407079\&> (in Arabic). 


$$
\begin{aligned}
& \text { Poverty, destruction and humiliation } \\
& \text { وبعهده الوطن صار سجن لكل دار } \\
& \text { prison in each house } \\
& \text { Bمكن يقدر يستوعب - مشار } \quad \text { Bashar might be able to understand } \\
& \text { Or he might collapse } \\
& \text { O Bashar, father of reform, } \\
& \text { The Syrian nation is not happy } \\
& \text { It only demands freedom. Leave us alone. } \\
& \text { You say: “These are conspiracies } \\
& \text { And the revolution is but chatter.” } \\
& \text { بتقتل شعبك وتدمر يا ظالم كيف مرتاح؟ } \\
& \text { you despot. [So,] how can you be happy? } \\
& \text { I ما همك مين... ومين راح } \\
& \text { And you are in the mood to celebrate }
\end{aligned}
$$

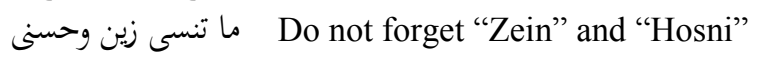

$$
\begin{aligned}
& \text { This day has passed as shameful... shameful... } \\
& \text { shameful. }^{28}
\end{aligned}
$$

This song directly engages the regime and rejects its promises of reform. The narrative of resistance has moved beyond the stage of accepting state concessions as a solution to overcome a political crisis. In the past, regimes in the region would initiate economic reforms to diffuse political tensions. ${ }^{29}$ Declaring, they are "not hungry," the subjects of the song reject economic solutions to assuage political crises. Unlike the previous poem that indicated that regional Pan Arab talk was a distraction, this work focuses strictly on domestic politics with the point that hunger for freedom cannot be satisfied with economic solutions. In essence, the people are unveiling the regime's agenda and ridiculing it. The reforms only succeeded in bringing "poverty, destruction and humiliation." The people's peaceful revolution is contrasted with that of the militant state. The people demand freedom, fully cognizant of the police state's violent reaction. After all, they are accustomed to living in one large "prison."

This song makes several references to Hafez al-Assad, Bashar's father who ruled Syria from 1970 to 1999. Labeled the "father of reform," the song makes clear connections to a continued legacy under Bashar, also referred to as "father of reform." This is a strong indication that the connections made during the resistance refer to the patterns made famous by the elder Assad. The song reminds Bashar of the violent history of his father's

$28<$ 〈http://www.youm7.com/News.asp?NewsID=407079\&>.

29 Protests throughout the Middle East beginning in the late 1980s were referred to as "bread riots" as citizens reacted to food shortages and cuts in state subsidies. 
rule and demand that he simply "leave them alone" so they may be able to attain freedom. This reflects an attempt to move beyond negating the regime's discourse in favor of a complete disconnect, pleading for Bashar to just leave them alone. A warning follows. Assad is reminded of the fate of other Arab leaders, Hosni Mubarak (Husnī Mubārak) of Egypt and Zein al-Aabideen (Zayn al-'Ābidīn) of Tunisia. Bashar is given one last chance to leave unharmed. He has two options: "Bashar might be able to understand or he might collapse." Thus, he either leaves Syria like Zein al-Aabideen or he will collapse like Hosni.

This song also makes clear that the "revolution is not chatter," a promise to resist until justice prevails. The regime refuses to acknowledge societal grievances, relying on one final weapon for survival, a weapon that knows neither logic nor mercy: violence. Although such tactics level towns and cities and kill thousands of innocent people, they cannot triumph over the collective will of the people. The song warns that if Assad is to learn anything from Egypt and Tunisia, it is the fact that it is only a matter of time for despised leaders to be ousted.

Although Assad made repeated promises for reform in his speeches, this song leaves no room for dialogue on reform. It also takes issue with Assad's claims that the uprising is a conspiracy and that it is his duty to protect the Arab nation from imperialism. They do not engage or entertain this narrative but focus instead on their "demand" for "freedom." According to this new narrative, there is no discussion of freedom and liberation from the enemy, Israel or colonialism. Rather, it is freedom from the humiliation of Arab autocracy. Since the creation of these states, Arab leaders used imperialism, conspiracy theories, and the threat of Israeli aggression to rule by decree and this song is but one example of the movement beyond old discourses and the creation of new ones.

\section{Slogans and the Efficiency of Repertoires}

The use of various kinds of slogans is one of the most efficient ways to oppose the regime in demonstrations across the Arab world. They are simple, pithy and catchy. Hundreds of slogans from the Syrian uprising reveal a great deal of political engagement with the regime. Unlike poetry and music, slogans are short, easy to memorize and are accessible to a larger segment of the population. Also, they unify the spirit of the uprising because they are often recited in different parts of the country at the same time. Thus, they act as a collective response to current political events. The following slogans reflect some of the people's demands and aspirations:

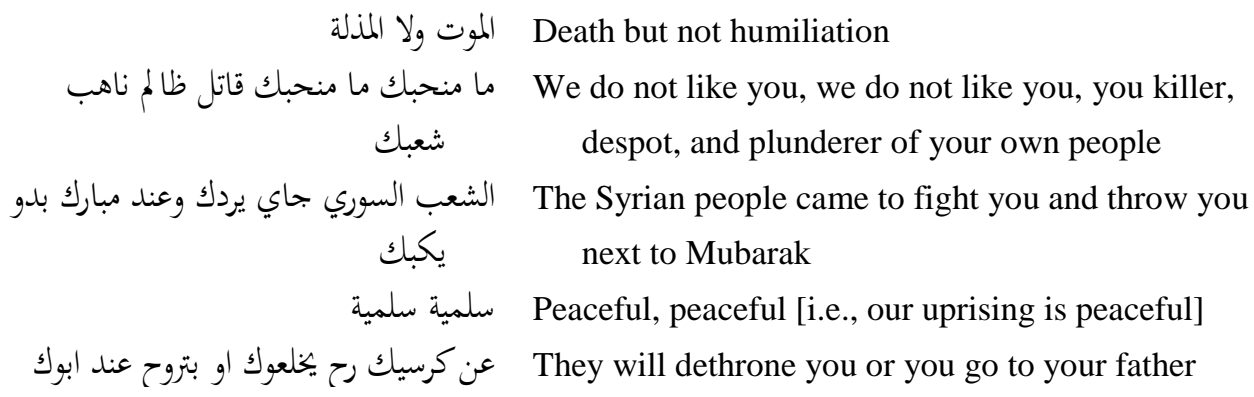

$J A I S \cdot 13$ (2013): 169-190 


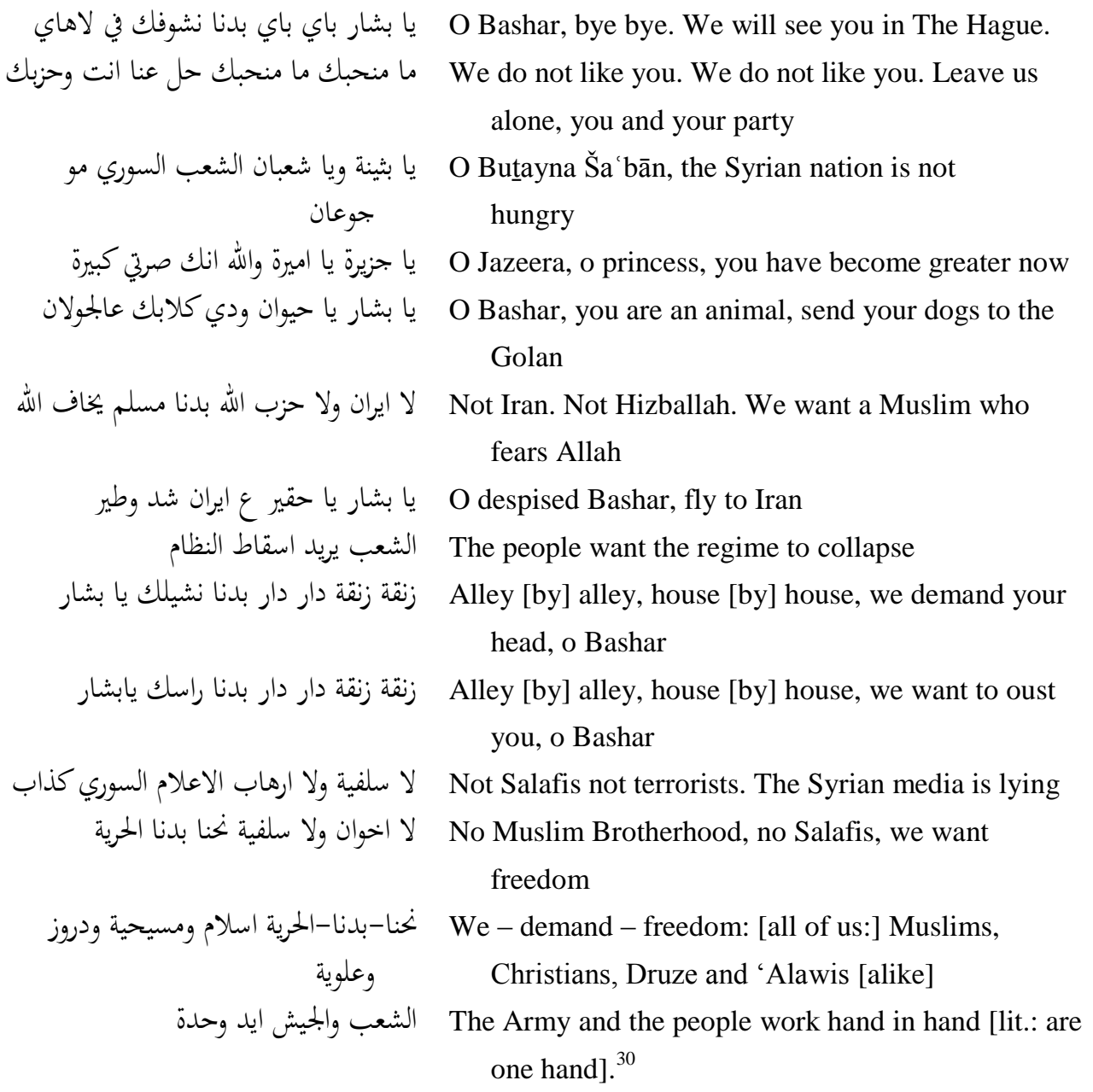

The significance of these slogans is not only the recurrence of themes and issues treated in the poems and song we discussed above, but also the introduction of new material to the revolutionary scene. On one hand, these slogans bring to the discussion the involvement of other parties and countries and their support of the Syrian regime. On the other hand, they praise and applaud the support of external media of the revolt. These slogans criticize the Iranian intervention in the uprising: "Not Iran. Not Hizballah. We want a Muslim who fears Allah," and "Bashar, you despised ruler, fly to Iran." They lay claim to their own revolution. They also praise the work of al-Jazeera, which depicts Bashar as "the killer," supported by a "lying" Syrian media: "O Jazeera, O princess, you have become greater now." Furthermore, the slogans maintain that the uprising has a peaceful dimension,

$30<$ http://www.saida7.com/t12436-topic> (in Arabic). 
despite the fact that it has turned violent. It is also not a Muslim Brotherhood, Salafi or terrorist revolution, as portrayed by Assad. The people are keen on the regime's effort to put a terrorist face on the revolt and to instill fear in those whose support to the uprising as equivalent to support for al Qaeda. ${ }^{31}$ The slogans also address the regime's goal to foster sectarianism as they declare: "We demand freedom: we are Muslims, Christians, Druze and Alawis." Syrians reject the notion that Syria will devolve into a sectarian war in the absence of Assad. The try instead to focus on unity, freedom, and equality, despite the fact that over time the crisis has developed a sharp sectarian character. The slogans are no longer simply working to undermine the regime's narratives. They are chants to the world, holding everyone accountable for the course of events. The resounding theme throughout is that the people will eventually triumph over Bashar, even if the world's superpowers are idle.

\section{Conclusion}

The revolt in Syria allows us, for the first time in contemporary Syria, to move beyond Wedeen's individual transgressions, to a preliminary discussion on collective transgressions in cases of transitions from authoritarian rule in the Middle East. Her work was the first step in debunking the "apathetic Arab" myth by showing an active, vibrant and resistant Syrian population decades earlier. With the devolution of power in Syria today, those individual acts of evading censors have taken on a life of their own in the reconstruction on Syrian national identity. In essence, although there was strong evidence that ordinary citizens "resisted" the state in the past, the collective themes and symbols of resistance have never been catalogued. The strong evidence of connection between the regime's survival strategy of rhetoric and its impact on the form and nature of the protests further highlights the importance of symbolism and spectacle during this revolutionary moment. Although this argument will not get us closer to predicting political outcomes such as transitions, it allows us to document the methods and tactics used by Syrians in the contestation and reconstruction of their identity. The protesters underwent a period of socialization that facilitated the forging of a counter-culture to delegitimize Assad's claims. Irrespective of the outcome, their expressions are ultimately revolutionary in the sense that they violate the engrained symbols of power and use those symbols to empower their movement.

31 In the early days of the revolt, the protesters were mainly peaceful and armed resistance was homegrown. As the crisis continued, fighters from outside Syria have joined the uprising. The resistance movement is not monolithic and it does not declare a unity in opposition, especially as the conflict takes on a more regional tone. 


\section{References}

BADAwI, Ibrahim el Makdisi, Samir. 2007. "Explaining the Democratic Deficit in the Arab World". The Quarterly Review of Economics and Finance 46: 813-831.

BELlin, Eva. 2004. "The Robustness of Authoritarianism in the Middle East." Comparative Politics 36,2 (Jan. 2004): 139-157.

Boullata, Issa J. (ed.). 1980. Critical Perspectives on Modern Arabic Literature. Three Continents, Washington, D.C.

BRynen, Rex (co-editor and contributor, with Bahgat Korany and Paul Noble). 1995 and 1998. Political Liberalization and Democratization in the Arab World. Volume 1: Theoretical Perspectives. - Volume 2: Theoretical Perspectives. Lynne Rienner, Boulder.

DiAmOND, Larry J. 2002. "Thinking About Hybrid Regimes". Journal of Democracy 13,2 (Apr. 2002): 21-35.

— . 2008. "The Democratic Rollback: The Resurgence of the Predatory State." Foreign Affairs 87,2 (March/Apr. 2008): 36-48.

FAWCETT, Louise (ed.). 2009. International Relations of the Middle East. Oxford University Press, Oxford.

Fawn, Rick / Hinnebusch, Raymond. 2006. The Iraq War: Causes and Consequences. Lynne Rienner, Boulder.

FeITH, Douglas. 2009. War and Decision: Inside the Pentagon at the Dawn of the War on Terrorism. Harper, New York.

FILALI-ANSARY, Abdou. 2012. "The Languages of the Arab Revolutions." Journal of Democracy 23,2 (Apr. 2012): 4-18.

FisH, M. Steven. 2002. "Islam and Authoritarianism.” World Politics 55,1 (Oct. 2002): 4-37.

FJELDE, Hanne. 2010. "Generals, Dictators and Kings: Authoritarian Regimes and Civil Conflict 1973-2004”. Conflict Management and Peace Science 27,3 (July 2010): 195-218.

GEDDES, Barbara. 1994. "Challenging the Conventional Wisdom". Journal of Democracy 5,4 (Oct. 1994): 104-118.

Henry, Clement M. / Springborg, Robert. 2001. Globalization and the Politics of Development in the Middle East. Cambridge University Press, Cambridge [etc.].

IssTAIF, Abdul-Nabi. 2002. "Forging a New Self, Embracing the Other: Modern Arabic Critical Theory and the West-Luwīs 'Awaḍ.” Middle Eastern Literatures 5,2 (2002): 161-180.

JABRA, Jabra Ibrahim. 1980. "The Rebels, the Committed, and Others: Transitions in Arabic Poetry Today.” In: Boullata (ed.) 1980: 191-205.

KASSAB, Elizabeth Suzanne. 2010. Contemporary Arab Thought: Cultural Critique in Comparative Perspective. Columbia, New York.

Kelidar, Abbas. 1993. "States Without Foundations: The Political Evolution of State and Society in the Arab East." Journal of Contemporary History 28,2 (Apr. 1993): 315-338.

KLEMM, Verena. 2000. "Different Notions of Commitment (Iltizām) and Committed Literature (Aladab Al-multazim) in the Literary Circles of the Mashriq". Arabic \& Middle Eastern Literature 3,1 (2000): 51-62.

LeVITSKy, Steven / WAy, Lucian. 2002. "The Rise of Competitive Authoritarianism”. Journal of Democracy 13,2 (Apr. 2002): 51-65.

LinZ, Juan J. 2000. Totalitarian and Authoritarian Regimes. Lynne Rienner, Boulder.

NGŨGĩ Wa Thiong'o. 1986. Decolonising the Mind: The Politics of Language in African Literature. J. Currey, London.

PRATT, Nicola. 2007. Democracy and Authoritarianism in the Arab World. Lynne Rienner, London.

Rogan, Eugene. 2009. "The Emergence of the Middle East into the Modern State System". In: FAWCETT (ed.) 2009: 21-43.

Ross, Michael L. 2001. “Does Oil Hinder Democracy?” World Politics 53,3 (Apr. 2001): 325-361. 
SCHEDLER, Andreas. 2002. "The Menu of Manipulation". Journal of Democracy 13,2 (Apr. 2002): 36-50.

ThiONG'o, Ngũgĩ Wa $\rightarrow$ NGŨGĩ Wa Thiong'o.

Tilly, Charles. 2008. Contentious Performances. Cambridge University Press, Cambridge.

UlfEDLER, Jay. 2005. "Contentious Collective Action and the Breakdown of Authoritarian Regimes." International Political Science Review 26,3 (July 2005): 311-334.

WedeEn, Lisa. 1999. Ambiguities of Domination: Politics, Rhetoric and Symbols in Contemporary Syria. University of Chicago, Chicago.

ZAKARIA, Fareed. 1997. “The Rise of Illiberal Democracy”. Foreign Affairs 76 (Nov.-Dec. 1997): 22-43.

Internet sources

http://www.homsnet.com/forum/showthread.php?p=557171 (in Arabic).

http://www.ibtesama.com/vb/showthread-t_273529.html (in Arabic).

http://www.saida7.com/t12436-topic.

http://www.youm7.com/News.asp?NewsID=407079\& (in Arabic).

Waed Athamneh / Caroleen Marji Sayej, Connecticut College, New London CT 06320

4 Waed.athamneh@conncoll.edu

$\checkmark$ Caroleen.sayej@conncoll.edu 